\title{
Katrin Flikschuh and Lea Ypi (eds.), Kant and Colonialism: Historical and Critical Perspectives
}

\author{
Ronald Tinnevelt
}

Katrin Flikschuh and Lea Ypi (eds.), Kant and Colonialism: Historical and Critical Perspectives, Oxford: Oxford University Press, 2014, 255 p.

Within the domain of the philosophy of race, the work of Immanuel Kant has sparked a lively debate among scholars. Although being often described as one of the key figures in the history of cosmopolitanism - emphasizing the equal moral worth of all persons - many theorists have also pointed at Kant's endorsement of a racial hierarchy in essays like 'On the Use of Teleological Principles in Philosophy' (1788). The implications of Kant's views on race for the universality of his moral theory, however, are interpreted quite differently. Some theorists are very skeptical and argue that Kant's philosophy - especially his anthropology and geography - contains 'expression of a virulent and theoretically based racism, at a time when scientific racism was still in its infancy' (Bernasconi, Kant as a Unfamiliar Source of Racism, 2002: 145) or that it offers 'the strongest, if not the only, sufficiently articulated theoretical philosophical justification of the superior/inferior classification of "races of men" of any European writer up to his time' (Eze, The Color of Reason, 1997: 129). Others accept the fact that Kant expressed racist beliefs but deny that Kant's 'basic critical philosophy and moral theory' is infected with a form of deep racism (Hill and Boxill, Kant and Race, 2001: 449) or argue that Kant changed his mind about race during the 1790s and that he can, therefore, still be seen as one of the champions of cosmopolitanism (Kleingeld, Kant and Cosmopolitanism, 2012).

Interestingly - and with this we come to the topic of Flikschuh's and Ypi's volume Kant and Colonialism - a similarly structured debate has developed regarding Kant's position on colonialism. Although he never developed a systematic theory within this domain, the few passages in Kant's work dedicated to the topic display an analogous kind of ambiguity or tension as can be found in his reflections on race. The ninth proposition in 'Idea for a Universal History with a Cosmopolitan Aim' (1784), for example, contains the following well-know lines: 'if one starts from Greek history (...) then one will discover a regular course of improvement of state constitutions in our part of the world (which will probably someday give laws to all the others)' (AA 8:29, my emphasis). Or take the subsequent claim from the 'Doenhoff Lectures on Physical Geography' (1782): '[t]he current fate of India depends as little on the French as on the English, but this much is certain, that if they were to be ruled by a European sovereign, the nation would become happier' Colonial practices are then not only tolerable but perhaps also necessary for progress. At the same time, however, it is quite easy to find a strong condemnation of most forms of colonialism in 'Toward Perpetual Peace' (1795) and 'Metaphy- 
sics of Morals' (1797). After having raised the question whether it shouldn't be allowed to found colonies in the 'great expanses of land in other parts of the world' - land that would otherwise remain uninhabited and unused - Kant leaves no doubt about his response: 'it is easy to see through this veil of injustice (Jesuitism), which would sanction any means to good ends. Such a way of acquiring land is therefore to be repudiated' (AA 6:266).

These different views of Kant regarding the permissibility of colonialism not only raise several important and challenging questions but also show the need of a systematic exploration of Kant's thoughts. Although more has been written on the topic in the past - also by the contributors themselves - Kant and Colonialism rightly claims to be the first collection dedicated to such a systematic undertaking. The main aim of the volume is a limited one. The emphasis in the different contributions is 'on exploring the problem of colonialism as Kant came increasingly to perceive it from within the framework of his cosmopolitan thinking' (p. 9). And because the chapters work 'within the parameters of Kant's Eurocentric cosmopolitanism' (p. 10), the collection doesn't contain a detailed or comprehensive engagement with the writings of theorists like Tully or McCarthy who explicitly focus on the effects of Kant's Eurocentricism for current cosmopolitan debates.

How to understand Kant's view on colonialism? What explains the 'gradual shift in Kant's overall assessment of European dealings with non-European peoples' (p. 9)? What role do cosmopolitan right, international trade, war, and land claims play in Kant's thoughts? What kind of wrong is colonialism and can claims to restoration be rightly made in the context of colonial appropriation? These are the main questions being addressed in the volume. These questions, however, can only be convincingly answered if some kind of clarity can be reached regarding Kant's uses of the term 'colony' and 'province'. That is why the book starts with Anthony Pagden's critical analysis of the 'four accounts of settlements overseas' deriving from different 'historical and legal definitions of the Roman "colony" and the Greek apoika' (p. 19) - that Kant provides us with. Unfortunately, though, Pagden's interesting taxonomy of Kant's different conceptions of 'colony' and 'colonialism' has not been systematically taken up (with the exception of a few short references in the chapters by Kleingeld, Muthu, and Ypi) in the rest of the volume.

Pauline Kleingeld's chapter explicitly focuses on the gradual shift in Kant's thoughts on racism and colonialism. Kleingeld convincingly and meticulously argues that 'Kant's initial endorsement and his subsequent criticism of colonialism are closely related to his changing views on race' (p. 43); an endorsement of racial hierarchy that he dropped during the mid-1790s. Kleingeld, however, doesn't explore the reasons or motivations behind Kant's second thoughts on colonialism and racism. Lea Ypi is one of the few theorists who tries to provide readers with such an explanation (motivation) based on the place and development of Kant's notion of biological predisposition in his philosophy of history. In her contribution, Ypi places Kant's thought 'on race and commercial relations in the con- 
text of a systematic discussion of Kant's philosophy of history, its teleological principles, and the related development of Kant's theory of right and politics' (p. 100). Kant's understanding of judgment and natural teleology in the third Critique, after all, not only has important implications for the relation between moral theory and the philosophy of biology but also for his political and legal philosophy. Instead of seeing (international) trade as a guarantee for peace and progress, commercial relations 'simply illustrate the empirical conditions under which cosmopolitan right can be established' (p. 122). What matters first and foremost is the duty to create just social and political institutions.

Another exception that should be mentioned in the context of Kant's 'second thoughts' is Ian Storey's article in History of Political Thought (2015, 36/4) 'Empire and Natural Order in Kant's "Second Thoughts" on Race' in which he - like Ypi points to Kant's changing understanding of human judgments and its effect on his teleological view of history. Although both Ypi and Sankar Muthu (in his chapter on Kant's notion of 'unsocial sociability') refer to Storey's text, it would have been interesting to know Kleingeld's response to the proposals made by Ypi and Storey.

Arthur Ripstein and Peter Niesen analyze Kant's rejection of colonialism and subsequent claims for redress within the context of his views on international law and cosmopolitan right. Ripstein uses a practice-based argument - the idea that 'the norm relevant to a certain form of human interaction is in some sense to be found in the form of interaction itself (p. 163) - to argue that colonial practices can be objected to on three distinct levels: the impermissibility of securing access to new markets and acquiring territory on the basis of war, the objectionability of 'colonizing a people' instead of 'simply incorporating the territory into the conquering nation' (p. 147), and the wrong of disregarding their interests and right to self-determination while ruling the colony. The last two compound the wrong of the first.

By making a distinction between three levels of international law, natural (1), transitional (2), and public (3), Niesen, on the other hand, shows that Kant does leave room for claims to restoration in the context of colonialism. Restorative justice, however, only has a rightful place in the second and third domains but not in the first. Niesen also convincingly argues, for example with regard to preventive warfare, that the division between the different levels of international law can be used to show that 'Kant's positions in Toward Perpetual Peace and the Doctrine of Right (...) represent a single consistent theory' (p .173). The claims in the Doctrine of Right operate on the first level, those in Perpetual Peace on the third.

Unfortunately, not all chapters from this interesting and well-wrought book can be discussed within the limited confines of this review. All contributions in Kant and Colonialism, however, are of high quality and provide readers with a broad array of nuanced and stimulating insights in Kant's thoughts on colonialism and cosmopolitanism. 